\title{
The Role of Oral Tradition in Leslie Marmon Silko's Ceremony
}

\author{
Lecturer: HAMEED MANA DAIKH \\ Dept. of English, College of Education \\ University of Al-Qadisiyah, Al-Diwaniyah, Iraq
}

DOI: $10.37648 / \mathrm{ijrssh} . v 10 \mathrm{i} 04.020$

Received:20 th September, 2020; Accepted:29th October, 2020; Published: 31st October, 2020

\begin{abstract}
Silko's novel Ceremony has redeemed and reminded the other white Americans the status and the history of the land owner. Native Americans have been ridiculed for their ways of living, treatment, and education. Silko here wants to say that this oral tradition and storytelling have preserved the heritage of a nation and made the life possible and accessible. Without oral tradition, they will not have any history or existence. Silko shows the stories unfold, Tayo discovers his identity and place within his soul; the story represents a universe where he belongs. Silko has referred to through the novel that the main goal of the oral tradition in which she brought up is to engage the listeners and readers in the story that is told, to interlace listeners in the web of magical stories. In this way, Tayo and others will know how you belong. These traditions that incorporate Tayo into them have made this community. People tell stories about each other's families and they begin to create their identity emphasizes that she offers spaces and universes for their listeners. What Silko writes about is not about a particular person or community but it is about history and existence of a nation's existence.

Keywords: oral tradition, storytelling, Native American, and identity
\end{abstract}

The time of Ceremony (1977), Silko's (1948- ) novel is at the end of the second World War. The novel sketches the life of the characters of different depth. But Tayo, who is a Native American man, participated in that war and returned to his hometown in the reservation of Laguna for Indians. He was devastated physically and psychologically by the war. The war has left its scars on his psyche. He was a mixed-blood child, his mother has deserted him and she was addicted to alcohol. His aunt has raised him, who kept always reminding him of his dishonorable birth as of unmarried mother. He lived most of his life bearing on his shoulder the burden of her gratitude in return to her kind-heartedness, in addition to the sense of inferiority to Rocky, her son. The aunt brings him up as an open-minded Christian that disdains Laguna ways of life, which he considered traditional ones. They, Tayo and Rocky, took part in the war they did not come back together as they went only Tayo came back. Tayo was paralyzed to achieve his duty as a guardian for Rocky. Therefore, he has seen Japanese murdering Rocky brutally in the Philippines. (Elias 2001)

In the novel, Tayo's ordeal has two facets: the first is that the time when he gives up and despair fills him while he was watching Rocky his closest friend and 
brother murdered on the hands of Japanese after he has been taken captive, tortured brutally, and executed before him the battle field. These moments are turning points in his life, which turned him into another man loaded with that burden all lifelong. The second facet is that the torment Tayo suffered from more came from the bitter reality, which is his sensitivity to the policy of flagrant segregation and the fact that the whites killed his fellow citizens, Native Americans, whom they seem to like such humiliation. After failing to locate any sign of awakening of his people, Tayo was about to return to the veteran's hospital when his grandmother asks the traditional medicine man Ku'oosh to come to treat him. So, he starts reciting his ceremony on Tayo for fighters who have killed in action. This ceremony is not only a healing one but also constructs Tayo's identity in Ceremony in two ways. The first is that Tayo should fight to establish his own individuality on two levels. The first level is the personal one that is immediate family. The second level is the social one in which he has to integrate himself again with his post- war community. But, Tayo resists, on his personal level, with the sense of alienation, existence, and a sense of loss even in his family, which begins directly from his boyhood. At the universal shared level, he attempts to solve the riddle of the problem of affiliation to his community or reengagement in that community when he returned from the World War II. ( Mutia, 2013)

History and tradition have been constantly part and parcel of the natives style of living, which are conveyed orally from a generation to another through one main tradition, which is oral one. The tradition becomes the genesis that incorporates the essential cultural traditions of the majority of people. They are collective activities that provide knowledge and contain the principles and ideals that perpetually involved in the life of people that are changed in the community. They passed a huge cultural and intellectual mass of people's knowledge through long line of rings of traditions without using writing. Oral tradition adds flavor to life, it blows spirit in the body of the past to regenerate and redeem it. So, oral tradition is the sum of all intellectualities and knowledge of the past that are conveyed through word of mouth to resist the development of humanity until the present day. (Olamide, 2010)
An oral tradition can be fictional or factual; it may include fanciful components or truthful ones. As a matter of fact, oral tradition turns out to be possibly the freest literary type surviving in the world of literature. So, freedom in Ceremony is merely one evidence of that diversity. In order to be able to understand the notion of what is the meaning of story to the culture of Native what is oral tradition concept means to them, it is essential to give a definition for oral storytelling in specific. It is a tool of communicating fictional incidents in words and these words convey incidents into sounds and imageries in which listeners dynamically generate in minds. Therefore, stories are told in each culture as a novel way of entertainment, education or preservation of a culture. Especially in Native American storytelling, traditional stories function as a device of identity formation. Collective memory is passed on from one generation to another and preserved only in its orality, which orality attempts to establish itself as a satisfactory alternative foundation. (Alessandro 1992)

She is sitting in her room thinking of a story now, I'm telling you the story she is thinking. Ceremony, I will tell you something about stories,[he said] They aren't just entertainment. Don't be fooled. They are all we have, you see, all we have to fight off, illness and death. You don't have anything if you don't have the stories (Silko, 1986, p.21)

These lines emphasize the significance of oral tradition and rites in the novel Ceremony. The author employs orality as a framing strategy, which covers the entire novel to generate a real image of the route that Native Americans employed to enter culture and traditions. The stories of Pueblo, which is drawn in the novel are kinds of tales oral by their traditional nature created and existed for specific and certain community. It means they are not fit for another kind of society of at least they do not stimulate the same memories or carry the same history for the readers of other communities. The tribe members are assigned for certain tasks and jobs, for example the job of telling stories. Not anyone is qualified to assume this job because it is crucial and very important job since it instructs, educates, and guides the tribe members. But the main function is to convey the ancestors' knowledge and insight of the tribe to other generations. The same function is seen in the novel, where there is the discrete perception that these tales and 
stories belong to the Native Americans, where all knowledge and phenomena they have knowledge about them are given to the younger generation. Through this way, it is employed to explain different aspects of life and sciences as medicine, biological knowledge, ethics, and the most important thing is the process of creation. The world creation, existence, and its creatures are conveyed and justified by tales, stories, and rituals across generations inside the same tribe. The author here is a messenger of her tribe and its traditions that are elaborately distributed. The mythical contain included and shown in the novel tell the stories of the ancestors and retell them over and over in unpredicted and different ways that vividly establish the connection and continuity of the literary genre of oral tradition. (Reck 2009)

Silko explains to the reader that "in the belly of this story / the rituals and the ceremony / are still growing" (Silko, 1986, p.22). Silko believes that these curative activities may include the real essence of their traditional identity, which is woven in the ceremony healing characteristics that performed through orality. It is manifested and portrayed as "Thought Woman", the spider, describes, "the only cure/I know/ is a good ceremony"(Silko 1986, p.22). These tribes activities and ceremony are functioned to reserve and connect culture and tradition of the old time with the contemporary life, but oral tradition is no doubt believed to recreate entirety. The key idea here accentuates that in the literature of Native American, curative songs and ceremonials highlight restoration of completeness, since illness is a state of separation and split from the consistency of the total community. Through this path, oral tradition associates the notion of self of the individual and tribal individuality by curing of the illness and internal incompleteness.(Allen 2015)

Silko sees that everything tells their stories. In the indigenous convention and belief, knowledge is attained by practical aspect of life and communicated orally. Native Americans develop throughout a period of increasing cultural and political understanding, which worked as the guardian and conveyers of the traditional conventions and ceremonies of those folks. Silko provokes a fervent employment of the old rituals and conventions as a method of continuing the story. Ceremony is a "Grail fiction," where Tayo has passed through different challenges and ordeals that endow him a new ceremonial rebirth. The novel is welcomed as the sacred tale that transforms and gives man wisdom and enlightment. Silko has employed the language that is rich and expressive to the extent the reader thinks it is poetic language rather than prosaic one. In certain situations the language produces the influence of natural blooming beauty and magnificence of the tribal rites and ceremonies. The study at the modern American universities never made Silko forgets her unforgettable glorious past, and she is able to weave a beautiful fabric of her traditions in her native novel to be a real and honest representative of her people. The use of universe symbolically and its repeated nature of time reaffirms the author's love for the ceremonial old times of her grandfathers. Through her novel, she writes every word to produce and create tales and each one of these tales could generate limitless tales like unlimited utterances of the language. Native Americans are portrayed as the liberator of the earth who respects all its creatures. (Beena 2010)

As in Ceremony and other works to the present time, Silko's method of writing and views have been to some extent identical to certain degree to the oral storytelling nature and the diversity of life actions as the written ones, which are part of her real life when she is brought up at Laguna Pueblo. Based on cultural anthropological and oral tradition, Laguna is constantly among the best places for the author, which is adjustable society in the Southwest region. Most of the tales encompassing oral tradition of Laguna, the hometown of the writer, that reserves and witnessed the intricate plans of struggle and integration, which prepared individuals to encounter challenges that are imposed by the external forces. Silko adds to her work the flavor of her town to keep her mediate over her culture and metamorphosis of spirit, which is the ultimate goal of her novel. Silko's innovative view, over and over, hails the metamorphosis influence of the tale and place that work together to heal the life they enjoy.(WITSCHI 2011)

"Hama-ha" tales are scattered through Ceremony, which are fragments and pieces of ancient tales and stories, or as the people of Laguna named them even in nearby Acoma town. These tales have a function to guide familiarize readers with these tales and stories in similar time frame and the locations of the tale that Tayo, who 
lives the events of the twentieth-century but realizes that the ultimate outlet and salvation is to return to older times of his tribe. These pieces of tale, or implanted texts, remind the audience that the people's long stories comprise examples and practices for the whole thing that occurs in the people's life. It could be anticipated that the majority of the "hama-ha" mythical or traditional tales included in Ceremony as the tale of the feud of the family among the first sisters, Corn Woman and Reed Woman; the gambler "Kaup'a'ta" story, that on one time restrained the clouds from raining; the Arrow boy story that removes weapons of the "Gunnadeyah" sorceresses through his ability of insight to see what they plan to do; and the story of lengthy nine-part of the upcoming of "Pa'caya'nyi" and "Ck'o'yo" medication to the community and the resulting leave and Our Mother healing "Nau'ts'ity'I" that include vivid practices and examples in sowing the seeds of oral tradition of ethnographic history of Laguna. Silko has taken her readers through the materials taken from the story of Navajo and ceremony, especially in the incident happens in the Chuska Mountains, where a revered old Navajo "hataali," Betonie, who is a singer or a "medicine man", passes a curative rites, which brings into line Tayo with the story of ghost way of a hunter that is young and his human personality is restored when it had been taken by a Coyote.(Porter and Roemer 2005)

The protagonist of Ceremony is a mixed- blood man like Silko who is a mixed- blood as well, but this does not prevent Tayo to search for his salvation. The last resort he finds is on the mountain of the witch, which means he has to go back to his roots and traditions and the only way of healing him is the oral tradition, which he forgets about:

The word he chose to express "fragile" was filled with the intricacies of a continuing process, and with a strength inherent in spider webs woven across paths through sand hills where early in the morning the sun becomes entangled in each filament of web. It took a long time to explain the fragility and intricacy because no word exists alone, and the reason for choosing each word had to be explained with a story about why it must be said this certain way. That was the responsibility that went with being human, old Ku'oosh said, the story behind each word must be told so there could be no mistake in the meaning of what had been said; and this demanded great patience and love. (Silko 1986)

When Tayo returned his house from the war, he suffered from sickness and emotional wound. He stayed at the Veteran's Hospital for a short period but this does not help him a lot. He regains somehow his strength, and when he is good enough to leave his bed, his grandma makes an appointment for him to meet the medicine man, Ku'oosh. Ku'oosh is a venerable man, who starts ceremony by re-reading the names and places of sacred places of Laguna over and over. He explains how does that community understand the world. The description of Spider Woman who is an important mythological figure in Pueblo mythology, the web image they use is the most suitable one for portraying their view to the world. All through the novel, different animals and vegetation are used as references for the deep association the Pueblo community have with the world especially the natural one. The stress of choosing the appropriate words is important since each curative word has its weight and significance; it is an organized and delicate process. So, the specific selection of distinct words is highly important. Silko has insisted on this kind of selection, where the reader is retold that though readers may read and appreciate Ceremony, it does not give readers ample admission to all elements of the original real story or more important to the culture of Laguna.(Sparknotes 2020)

Native people have a sole tool of communicating their heritage, history, and culture, which is orality that represents the cornerstone of their life. It is through this tool, they succeeded to organize their metaphysical beliefs and deities in a rational and logical piece. The axis of Native American culture depends on orality, and this may include everything as medicine, history, morality, and nature, which are transmitted in the series of stories. Orality becomes the reference that comprises all their heritage and knowledge. The crucial and sensitive jobs are assumed by elders including telling stories for a community, where telling story is deeply a communal incident. They acquired experience and follow certain strategies to tell stories that are meant to convey knowledge and information that will be memorized. In order to make stories attractive and digestible, stories should be rhythmic and could be sung that included a great deal repetition. This type of 
tellingstory is narrated in a ceremony that takes the shape of poems and songs that frame the central narration in the beginning of the story and end of it. The stories are newly authored but they are Pueblo traditional stories, which are famous in the native community rather than in the novel context. The tale of Tayo echoes the stories that are traditional but it is an original one.(Allan 2002)

Silko uses Native American oral tradition of medicine and myth as raw materials for her style of writing. She succeeds to establish an agreement of forms and concentrated match that works to support the structure of the novel and bridge the gaps of the novel's plot, that impacts on purposely unconnected feature of the plot. The feeling that separates and disintegrates characters in the beginning of the novel, it gives the power of integration and connection of different times in the end of the novel. The time becomes linked in one chain, where past is connected with the present heading to the future. Sometimes, there is a necessity for the readers to use certain digressions in narration and displacements to have a wider image and have enough space to mediate the details. Definitely, they are the story and they aren't actually dislocations and digressions. Tayo has done this when he got home:

They unraveled, the dead skin, Coyote threw on him. They cut it up, bundle by bundle. Every evil, which entangled him was cut to pieces.(Silko, 1986, p. 238)

The ritual of hoop that comes in the middle part of the novel comes in the middle of occasions that happen before and after the ceremony itself. So, it turns to be the shared symbol in the content and form of Ceremony. For, as Betonie tells Tayo, "It is a matter of transitions, you see; the changing, the becoming must be cared for closely. You would do as much for the seedlings as they become plants in the field."(Silko, 1986, p. 128).

Thus, oral tradition remains the source of effect that alters the written literature of Native American. In respect to the significance and continuous impact of the oral literature, Porter refers to that:

Indian oral traditions are not fragile: in spite of tremendous adversity they survive and continue to grow, reflecting change and diversity within the cultures that produce them and those cultures' relationships over time both with other Indians and non-Indians. (Porter \& Roemer, 2005, p.58)

The majority of the native writers seek to convey their traditions to non-Indians readers to read and learn some information about Native Americans mythology and literary oral history to appropriately comprehend their literature since it is unexplained in the form of writing. Silko follows the path of orality of narration as raw matter for her novel and embraces oral storytelling as a technique. She masterly attempted to give authenticity and weight for her narrations to be reliable and have native expressions. There is no doubt that Silko's innovative talent enables her to construct raw materials from the surrounding world observations and beliefs, which are mainly contradictory to the understanding and impressions of the white. Ceremony wields and integrates the oral heritage of the Indian that persists along the old times with the Eurocentric literature and history; it wields the mythical and the actual that hazes the limits between reality and fiction.(Mohsin 2012)

Silko attempts to show that it is not necessary to abandon traditions to be a civilized man or to give your back to your heritage to be accepted to the white man. Tayo is an example of that long bitter journey. He came back from the war suffered from posttraumatic stress disorder and this condition jails his soul in the eternal overthinking and suffering. The only way that gives him a rebirth is the "spider woman," whom she can change her shape from giant spider to beautiful woman or old wise one. She interfered to chant and murmur to save Tayo's life from the claws of his monster, "He was not crazy; he had never been crazy. He had only seen and heard the world as it always was: no boundaries, only transitions through all distances and time."(Silko 1986, 227) Silko wanted to prove that another life can be given through oral tradition, Native American traditions not the white American that save Tayo. Silko believes in the power of stories to locate people, to endow them with a sense of place, peace, and to remind them of their place in the universal order. Coming from Laguna Pueblo, she belongs to a community of indigenous people who were not displaced, relocated or terminated by federal agencies. Hence, as an author she has a very strong sense of connection between her family home, traditional stories and the function of oral tradition.(May Dennis 2006) 
The novel excessively employed oral traditions as a technique of the author, and this use has a couple of objectives. The novel endeavors to go beyond the sense of cultural estrangement that Native Americans encountered on the hands of the whites. In the same vein, there is a belief that most natives adhere that their method of recognizing the world could assist white community towards reconciliation. The novel in its current form has the responsibility to carry the heavy burden of developing the Western world through enhancing and enriching beliefs that seen primitive for a long period of time, and there is a gap of understanding each other. These beliefs are deeply implanted and involved in the Western society to certain degree, which echoed a kind of mentality seems strange and sick to native cultures. Silko never gives up embedding oral traditions in her novel, which is not safe adventure because adopting the text in the print form will lead to the disappearance of oral materials, which are very essential to the novel. When oral traditions that used to communicate across generations will lose their basic function when transformed into written text. They are employed to reinforce ancestors' beliefs and traditions that passed through the different tests of ages and introduced ways of staying alive in the very severe conditions. Therefore, the time repeats itself, as with Tayo, who is cured by the same old traditions. So, these traditions have played a major role to the tribes and members of these tribes because they work on wielding the tribe into one unity. The novel succeeded to clearly creating that sense for all readers that orality is the lifesaving factor for the natives.(Kumar 2015)

\section{CONCLUSION}

Silko's Ceremony is the real representative of the Native American writers that attracts so much attention and debate in the literary circles. The techniques the writer adopted, storytelling and oral tradition, enable her to be the messenger of her people. Silko is after introducing and preserving that oral tradition is the only tool that ensures the continuity of this decisive tradition of the natives' life. Telling story for Silko is the boat that carries the heritage of the natives and leading the boat to safety means to preserve the history of her ancestors. In this novel, telling story is the guarantee for next generations that nothing will be lost or even forgotten. In the tales, the fragments of these tales are collected regardless of their time since they represent undying tradition that will live forever. The novel's protagonist, Tayo, is a true image of postwar victims, who suffered war atrocities. He realized that the only outlet for his disorder is to accept and return to his hometown and sing the song of the sunrise in consequence to the first meeting with the enigmatic woman, who magically cured him. Tayo understand that there are close and important links between the experiences he went through his life and those of his ancestors. This realization is highly important because it unveils the attitude of the story of certain individual who has insights about the ways of life of his community and its connection to the oral traditions of his people. Orality, as Silko, wants to deliver the message that it preserved the huge history with its heritage and traditions of the native community. If this way is not in hand, most of the native history will vanish and disappear forever.

\section{REFERENCES}

ALESSANDRO, PORTELLI. 1992. THE TEXT AND THE VOICE: Writing, Speaking, and Democracy in American Literature. Columbia: COLUMBIA UNIVERSITY PRESS.

Allan, Chavkin. 2002. Leslie Marmon Silko's Ceremony: A Casebook. Oxford: Oxford University Press.

Allen, Paula Gunn. 2015. The Sacred Hoop: Recovering the Feminine in American Indian Traditions. http://qut.eblib.com.au/patron/FullRecord.aspx?p=1914394.

Beena, Yadav. 2010. “The Survival of Native American Identity in the Writings of Leslie Marmon Silko.” India: University of Lucknow.

Elias, Amy J. 2001. Sublime Desire: History and Post-1960s Fiction. Parallax : Re-Visions of Culture and Society. Baltimore: Johns Hopkins University Press.

Kumar, Ravi, J. G. 2015. "Ceremonies of Culture a Study of Leslie Marmon Silko," International Journal of Multidisciplinary Approach and Studies, 02 (1): 7. 
May Dennis, Helen. 2006. Native American Literature: Towards a Spatialized Reading. 1st ed. Routledge. https://doi.org/10.4324/9780203968222.

Mohsin, Mohd. 2012. "Forging a Cultural Identity: A Study of Leslie Marmon Silko’s Ceremony and Select Short Stories." Thesis, Srinagar: University of Kashmir,.

Mutia, Rosalyn. 2013. "Multiculturalism and The Canon in American Literature: Why Teach Marmon Silko,” The Journal of Multicultural Society, Vol.4 (No.1): 76-93.

Olamide,Ayedun. 2010. “Oral Traditions.” In Oral Traditions, 24. University of Ilorin.

Porter, Joy, and Kenneth M. Roemer, eds. 2005. The Cambridge Companion to Native American Literature. Cambridge ; New York: Cambridge University Press.

Reck, Alexandera. 2009. "Leslie Marmon Silko's Ceremony: An Exploration of Characters and Themes." URL. Georgetown. 2009. https://faculty.georgetown.edu/bassr/218/projects/reck/alr.htm.

Silko, Leslie Marmon. 1986. Ceremony. 1 vols. New York: Penguin books.

Sparknotes. 2020. "Ceremony." Https:/Www.Sparknotes.Com/Lit/Ceremony/Quotes/. March 2020. https://www.sparknotes.com/lit/ceremony/quotes/.

WITSCHI, NICOLAS S. 2011. A C O M P A N I O N T O A John Wiley \& Sons, Ltd., Publication THE LITERATURE AND CULTURE OF THE AMERICAN WEST. 1st ed. USA. 